\title{
RESEARCH
}

Open Access

\section{Neurexin 3 transmembrane and soluble isoform expression and splicing haplotype are associated with neuron inflammasome and Alzheimer's disease}

Akitoyo Hishimoto', Olga Pletnikova², Doyle Lu Lang³, Juan C. Troncoso², Josephine M. Egan³ and Qing-Rong Liu $^{3^{*}}$ (D)

\begin{abstract}
Background: Synaptic damage precedes neuron death in Alzheimer's disease (AD). Neurexins, NRXN1, NRXN2, and $N R X N 3$, are presynaptic adhesion molecules that specify neuron synapses and regulate neurotransmitter release. Neurexins and postsynaptic neuroligins interact with amyloid beta oligomer $(\mathrm{A} \beta O)$ deposits in damaged synapses. NRXN3 gene variants have been associated with autism, addiction, and schizophrenia, however, not fully investigated in Alzheimer's disease. In the present study, we investigated an AD association of a 3'-splicing allele of rs8019381 that produces altered expression of transmembrane or soluble NRXN3 isoforms.

Methods: We carried out RT-PCR (reverse transcription polymerase chain reaction), PCR-RFLP (PCR and restriction fragment length polymorphism), Sanger sequencing, and in situ hybridization (ISH) assays for NRXN3 neuron expression and genotyping. Genetic associations were analyzed by $x^{2}$ tests, and ISH signals were analyzed by FISH v1.0 module of Indica Labs HALO software.

Results: We previously identified a functional haplotype in the $3^{\prime}$ region of neurexin 3 (NRXN3) gene that alters the expression ratios between NRXN3 transmembrane and soluble isoforms. In this study, we found that expression and ratio of transmembrane and soluble NRXN3 isoforms were reduced in AD postmortem brains and inversely correlated with inflammasome component NLRP3 in AD brain regions. The splicing haplotype related to the transmembrane and soluble NRXN3 expression was associated with $A D$ samples with $P=6.3 \times 10^{-5}$ (odds ratio $=2.48$ ) and interacted with APOE genotypes.

Conclusions: We found that the SNP rs8019381 of NRXN3 that is located adjacent to splicing site \#5 (SS\#5) interacts with the APOE \&4 haplotype and alters NRXN3 transmembrane or soluble isoform expression in AD postmortem cortex. Dysregulation of presynaptic NRXN3 expression and splicing might increase neuron inflammation in AD brain.
\end{abstract}

Keywords: Alzheimer's disease, Neurexins, Endocannabinoids, Apolipoprotein E, Alternative splicing

\footnotetext{
* Correspondence: qliu@mail.nih.gov

${ }^{3}$ Lab of Clinical Investigation, NIA-NIH, 251 Bayview Blvd, Baltimore, MD

21224, USA

Full list of author information is available at the end of the article
}

(c) The Author(s). 2019 Open Access This article is distributed under the terms of the Creative Commons Attribution 4.0 International License (http://creativecommons.org/licenses/by/4.0/), which permits unrestricted use, distribution, and reproduction in any medium, provided you give appropriate credit to the original author(s) and the source, provide a link to the Creative Commons license, and indicate if changes were made. The Creative Commons Public Domain Dedication waiver (http://creativecommons.org/publicdomain/zero/1.0/) applies to the data made available in this article, unless otherwise stated. 


\section{Background}

Non-familial and late-onset Alzheimer's disease (AD) is a common cause of dementia in the elderly. Emphases on classical AD neuropathological features, $A \beta$ neuritic plaques (A $\beta$-NPs), neurofibrillary tangles (NFTs), and neuropil threads are increasingly acknowledged to be accompanied by disrupted synaptic contacts and impaired glutamatergic neurotransmission $[1,2]$. While the $\varepsilon 4$ allele of apolipoprotein $\mathrm{E}(A P O E)$ gene makes a large contribution to the genetic bases of interindividual differences in vulnerability to $\mathrm{AD}$, the sizable genetic influences that remain after accounting for $A P O E$ are likely to arise from polygenic and/or rarer variants that each makes modest contributions to overall disease vulnerability.

Diffuse $A \beta$ fibrillar plaques are often observed in postmortem human brains with normal cognitive function [3-6]. Pathological A $\beta$ plaque formation around synapses with $\mathrm{A} \beta \mathrm{O}$ deposit correlates with memory loss and synapse dysfunction $[7,8]$. Neurexins were discovered as $\alpha$-latrotoxin (venom of black widow spider) receptors [9] and function as presynaptic cell adhesion molecules [10] that help to regulate the release of neurotransmitters, specify, and stabilize classical synapses, including the glutamatergic synapses that provide a focus for research in $\mathrm{AD}[1,2]$. Neurexin genes are among the largest genes (greater than one million base pairs) in the human genome, and the three mammalian neurexin genes NRXN1, NRXN2, and NRXN3 each display differential splicing events that provide thousands of neurexin isoforms on a background of longer $\alpha$-neurexin and shorter $\beta$-neurexin that arise from the use of alternative promoters [11]. The larger $\alpha$-neurexins contain three EGF-like (epidermal growth factor) domains each of which flanked by two LNS (lamin-neurexin-sex hormone-binding globulin) domains, a single transmembrane domain, and intracellular PDZ (PSD95-Dlg1-Zo1) domain that interact with intrasynaptic proteins $[10,12]$. Specifically, $\alpha$-neurexins are coupled to presynaptic calcium channels to regulate neurotransmitter release [13] and interact with postsynaptic neuroligins, leucine-rich repeat transmembrane proteins (LRRTMs), calsyntenins (CLSTN), a-dystroglycan (DAG1), GABA $\mathrm{A}_{\mathrm{A}}$-receptors (GABRAs), latrophilins $(A D G R L s)$, cerebellin $(C B L N)$-glutamate dehydrogenase (GLUD) complexes, synaptic cleft secreted neurexophilins (NXPHs), and intracellular PDZ-binding proteins [14, 15]. Neurexins' intracellular PDZ domains can bind to MINT1, MINT2, and CASK proteins [16, 17] that themselves bind to and stabilize the transmembrane form of amyloid precursor protein (APP) [18]. MINT1 and $M I N T 2$ are adaptor proteins that complex with conserved motifs in APP's C-terminal region to stabilize APP transmembrane forms and reduce secretion of pathogenic $A \beta$ cleavage products [19]. It is thus even possible that NRXNs-MINTs interaction complexes could alter APP protein processing. Soluble or secreted $\alpha-N R X N 3$ is produced by including extra exon 23 with four different intra-exonal spliced sites that encode four premature stop codons that abolishes the transmembrane and intracellular PDZ domains $[20,21]$. The smaller $\beta$-neurexin contains one LNS domain (no EGF domain), a transmembrane domain, and an intracellular PDZ domain. The $\beta$-neurexin acts as a brake for endocannabinoid 2-AG (2-arachidonoylglycerol) synthesis that retrogradely regulates presynaptic cannabinoid receptor 1 (CB1R)-mediated depolarization-induced suppression of excitation on AMPA and NMDA receptors that are involved in excitatory postsynaptic currents (EPSCs) [22]. APP cleavage enzymes of $\alpha$ - and $\gamma$-secretases can process $\beta$-NRXN3 into an $\mathrm{N}$-terminal extracellular domain $(80 \mathrm{kDa})$ and a C-terminal intracellular domain $(12 \mathrm{kDa})$. The enzymatic activities are altered by several single nucleotide polymorphisms (SNPs) of $\gamma$-secretase subunit presenilin 1 (PSEN1) that contribute to early-onset forms of familial AD [23]. Recent data identify roles of neurexin isoforms in several complex neuropsychiatric phenotypes that include autism [24-26], addiction [20, 27, 28], and schizophrenia [29, 30].

NRXN3 mRNA is the second most reduced gene after vacuolar $\mathrm{H}^{+}$-ATPase subunit gene ATP6V1E1 in $\mathrm{AD}$ hippocampus identified by bioinformatic analysis of $\mathrm{AD}$ and aging Gene Expression Omnibus (GEO) databases $[31,32]$. We have identified 3' region of NRXN3 haplotypes that are tagged by alleles of the SNP rs8019381, which is located near the end of NRXN3's exon 23 at a key splicing site [20]. Alleles of rs8019381 tagged NRXN3 produce the splice variants that include or exclude exon 23 coding for a single transmembrane domain; thus, transmembrane or soluble NRXN3 isoforms are transcribed and translated, respectively [20]. NRXN3 is expressed in neurons in brain regions that are implicated in mnemonic processes and in dementia-associated AD pathologies. For example, NRXN3 is expressed in the cerebral cortex and in the hippocampus that contains $\mathrm{AD}$-related senile plaques and neurofibrillary tangles [33, 34]. Differences in the properties of synapses in these regions could alter brain connectivity, and the altered ratio of transmembrane and soluble NRXN3 isoforms could lead to pathological A $\beta O$ accumulation at synapses.

We have thus characterized the patterns of expression of total NRXN3, $\alpha-N R X N 3$ and $\beta-N R X N 3$, and four $N R X N 3$ transmembrane and soluble splice variants in mRNAs extracted from postmortem middle frontal gyrus from pathologically confirmed $\mathrm{AD}$ and control individuals. We have sought AD-related differences in frequencies of NRXN3 haplotypes and tested whether the NRXN3 associations are dependent on the APOE genotype. Finally, we have found evidence for $N R X N 3$ association and interaction with $A P O E$ genotypes in previously 
reported genome-wide association datasets and for NRXN3 inverse correlation with inflammasome component NLRP3 in neurons of the AD hippocampus and cortex. Taken together, these data support contributions for common human NRXN3 haplotypes and altered NRNX3 transmembrane and soluble isoform expression in $\mathrm{AD}$ brain.

\section{Methods}

\section{Subjects: human samples}

Middle frontal gyrus postmortem brain samples of 121 European-American AD (38 men and 83 women with mean age $80.3 \pm 9.6$ ) were obtained from the Division of Neuropathology, the Department of Pathology, the Johns Hopkins University School of Medicine (JHUSOMI), whose diagnoses were all confirmed by autopsy [35].

Additional European-American comparison groups comprising 349 subjects were examined to document the distribution of NRXN3 polymorphism in the general American Caucasian population of the USA. One hundred sixty samples (107 men and 53 women with mean age $36.1 \pm 16.2)$ were obtained from Maryland Brain Bank (UMD) whose geographical location is close to that of $\mathrm{AD}$ subject collection. One hundred eighty-nine unrelated subjects (42 men and 147 women with mean age $51.2 \pm 14.9)$ were selected from pedigrees from the Collaborative Study on the Genetics of Alcoholism (COGA) [36]. We explored mRNA levels of NRXN3 isoforms in middle frontal gyrus postmortem samples from 58 pathologically confirmed AD subjects and 48 control subjects. We also explored the association between this NRXN3 haplotype and AD with 121 pathologically confirmed AD subjects and 349 control subjects.

\section{RNA isolation and cDNA synthesis}

Total RNA was extracted from the larger sized middle frontal gyrus samples available from 58 of the autopsy-confirmed European-American AD patients and 48 normal individuals dying without neurological disease (40 females $/ 18$ males, mean age \pm SD; $81.2 \pm 10.0$, PMI; $11.4 \pm 6.4$ from JHMI and 11 females/37 males, mean age \pm SD; 47.6 \pm 19.7 , PMI; $11.9 \pm 6.0$ from JHMI and
UMD) using Trizol (Thermo Fisher, Waltham, MA) protocol. Single-strand cDNA was synthesized from total RNA using SuperScript ${ }^{\mathrm{TM}}$ III One-Step RT-PCR System (Invitrogen, Carlsbad, CA, USA). Electrophoresis of all RNAs used for quantitative PCR revealed sharp 18S and $28 \mathrm{~S}$ ribosomal RNA bands; four samples with evidence for RNA degradation were eliminated on this basis.

\section{Quantitative RT-PCR}

For quantitative real-time PCR assessments of NRXN3 mRNAs, isoform-specific primers and minor groovebinding (MGB) TaqMan probes were designed using Primer Express Software (Table 1), common NRXN3 TaqMan probe (Hs01028186_m1), and endogenous control glyceraldehyde-3-phosphate dehydrogenase (GAPDH, Vic-labeled) which were ordered from Thermo Fisher (Cat\#4326317E, Thermo Fisher Scientific, Waltham, MA, USA). The relative fold change is calculated using the formula $2^{\wedge}\left(-\Delta C_{t}\right)$.

\section{Genetic testing}

Genomic DNA was extracted from blood or tissue samples from the individuals noted in "human samples" above. DNA from most AD and control samples was extracted from the middle frontal gyrus brain tissues using Qiagen genomic DNA kits. Genomic DNA for other subjects was extracted from peripheral leukocytes as previously described [37]. APOE polymorphisms were genotyped using PCR-RFLP assays as described [38]. The rs8019381 SNP was genotyped by direct Sanger sequencing as described [20].

\section{RNAscope in situ hybridization (ISH)}

Human postmortem hippocampus (1 control sample of Braak 0 and 3 AD samples of Braak 6) and middle temporal gyrus ( 2 control samples of each Braak 0,1 , and 2 and 2 AD samples of each Braak 4, 5, and 6) were used for triplex fluorescent ISH. Human RNAscope ISH probes were ordered from Advanced Cell Diagnostics Inc. (ACD, Hayward, CA, USA) for NRXN3 in C2 channel (20 ZZ pairs targeted region 1095-2035 of NM_001105250.2; Cat No. 525431-C2), NLRP3 in C1 channel (30 ZZ pairs

Table 1 Real-time PCR primers and MGB Fam-TaqMan probes for NRXN3 isoforms

\begin{tabular}{llll}
\hline NRXN3 & Forward primers & Reverse primers & MGB probes \\
\hline Hs01028186_m1 & NRXN3 TaqMan gene expression assay & & CCGAGTACAGGAGGTG \\
ex 22a24a & TGATCTTGTTTCATCTGCTGAATG & AAGGTGCACGAGTAGCAATAG & CCGAGTACAGATAAGAGTC \\
ex 22a24b & TGATCTTGTTTCATCTGCTGAATG $22 \mathrm{a} 24 \mathrm{c}$ & TGCTTGTAGCCACCTTCGA & CCGAGTACAGCAAAC \\
ex 22a23a & TGATCTTGTTTCATCTGCTGAATG & CCCGGAACCCGTCTGATT & CCGAGTACAGCCAGAAG \\
ex a1-2 & AGATGATCTTGTTTCATCTGCTGAA & CGGAGTGATCTAGCTGCATTAGAG & AACTGGAAAGTCTTTC \\
ex $31-18$ & GACATACAGACAGATCCCAAATCTTC & TCATGGTGCGGCCAGAA & AGGACACGCTGGCG \\
\hline
\end{tabular}


targeted region 2627-4008 of NM_004895.4; Cat No. 478021), and NEUN/RBFOX3 in C3 channel (20 ZZ pairs target region 720-2217 of NM_001082575.2; Cat No. 415591-C3). The positive control probes (Cat No. 320868) were POLR2A ( $\mathrm{C} 1$ channel), PPIB (C2 channel), and $U B C$ (C3 channel). The negative control probe was bacterium (Bacillus subtilis) gene DapB (Cat No. 320871). The cryostat sectioning of postmortem human brain samples, fixation, protease pretreatment, probe hybridization, pre-amplification, amplification, horseradish peroxidase reaction, and fluorescent labeling steps were described previously [39]. Zeiss LSM 880 confocal microscope was used to image fluorescent labeling. Amplification $\times 20 \mathrm{im}$ ages (two to three images for each brain sample) were analyzed by FISH v1.0 module included in HALO software with RNAscope ISH setting (Indica Labs, Corrales, NM, USA). The H-score $\left[\Sigma_{\text {bin0-4 }}\right.$ (ACD score or bin number $\times$ percentage of cells per bin)] were used to calculate mRNA expression for each probe based on the minimum intensity threshold (a value between 0 and 400).

\section{Statistical analysis}

Genetic associations were analyzed by $x^{2}$ tests. Deviations from Hardy-Weinberg equilibrium (HWE) were examined by $X^{2}$ test with $P<0.05$ as a deviation from HWE. Correction for multiple testing was not applied because of the a priori reason to focus on rs8019381 in this study. Power analyses used the program PS v2.1.31 [40]. Comparison of the ages in AD between the rs8019381 SNP genotype groups was analyzed using ANOVA. Logistic regression analysis was also applied using phenotype as the dependent variable, and the age, gender, APOE $\varepsilon 4$ allele, and rs8019381 genotypes as the independent variables. Statistical analyses of mRNA expression RT-PCR and ISH data were performed using PRISM (GraphPad Software, CA, USA) software. Differences in the mRNA expression levels based on phenotype (control vs AD or genotype CC vs $\mathrm{CT}$ and TT) were examined using two-tailed MannWhitney tests. Two-way ANOVA and two-tailed/unpaired Student's $t$ test using H-scores of ISH intensities were tested for any significant differences between NRXN3 and NLRP3 expressions in different Braak stages of MTG and HIP samples. Linear regression of $\mathrm{H}$-scores of each ISH probe was used to fit straight lines through control and $\mathrm{AD}$ data sets with different Braak staining stages and statistically calculated for any significant differences. $P<0.05$ was considered significant for comparisons of expression levels. Spearman's rank correlation coefficient analyses were used to assess the contributions of age, sex, and postmortem interval to the mRNA expression levels of each splice variant.

\section{Results \\ $a-N R X N 3$ and $\beta-N R X N 3$ mRNA expression in AD middle frontal gyrus}

We compared expression of $\alpha-N R X N 3$ and $\beta-N R X N 3$ in mRNAs extracted from the middle frontal cortices of human postmortem brain samples of $\mathrm{AD}$ and controls with different "splicing site 5 (SS\#5)" NRXN3 haplotypes defined by alleles of the rs8019381 SNP. Since controls displayed few rs8019381 T alleles, we compared control samples with $\mathrm{CC}$ genotypes to $\mathrm{AD}$ samples with $\mathrm{CC}$ genotype and to $\mathrm{AD}$ samples with either one or two $\mathrm{T}$ alleles $(\mathrm{CT} / \mathrm{TT})$. There were no significant differences between expression of $\alpha-N R X N 3$ mRNA in CC controls vs AD patients with either $\mathrm{CC}$ or CT/TT genotypes (Fig. 1a; two-tailed Mann-Whitney $P=0.067$ and $P=0.127$, respectively). By contrast, when compared with control individuals with CC genotypes, $\beta$-NRXN3 mRNA expression levels decreased by $30 \%$ and $48 \%$ in AD patients with CC and $\mathrm{CT} / \mathrm{TT}$ genotypes, respectively (Fig. $1 \mathrm{~b} ; P=0.0004$ and $P<0.0001$, respectively). We identified a mild significant correlation between age and either $\alpha-N R X N 3$ or $\beta$-NRXN3 mRNA expression levels in the combined groups (Fig. 2a; $P=0.0473$, Spearman $r=0.193$ and $P=0.0061$, Spearman $r=0.2648$, respectively). However, we identified neither a trend nor a significant correlation between age and either $\alpha-N R X N 3$ or $\beta-N R X N 3$ mRNA expression levels in the control groups (Fig. $2 \mathrm{~b} ; P=0.787$, Spearman $r=0.040$ and $P=0.386$, Spearman $r=0.128$, respectively). We also did not identify significant correlations between $\alpha-N R X N 3$ and $\beta-N R X N 3$ mRNA expression levels in the $\mathrm{AD}$ group and age (Fig. 2c; $P=0.253$, Spearman $r=0.153$ and $P=0.186$, Spearman $r=0.176$, respectively). In these $\mathrm{AD}$ samples, the positive slope of this regression line does indicate trends toward less NRXN3 expression in older individuals with AD phenotype. Neither gender nor postmortem intervals were correlated with these expression levels in control or AD groups (data not shown). In the $\mathrm{AD}$ subjects, there were no differences in expression of either $\alpha-N R X N 3 \quad(P=0.751)$ nor $\beta$-NRXN3 isoforms $(P=0.863)$ in individuals with haplotypes marked by $\mathrm{CC}$ vs $\mathrm{CT} / \mathrm{TT}$ genotypes.

\section{Genetic analysis}

Table 2 shows the genotype distribution and allele frequency of rs8019381 SNP for AD and control groups. The genotype distributions differed remarkably between the AD and control groups $\left(\chi^{2}=15.587, \mathrm{df}=2\right.$, $P=0.000413)$. The minor allele frequency of the rs8019381 T allele was significantly greater for the AD group than for the control group $(0.157: 0.070$, respectively; $\left.X^{2}=15.997, \mathrm{df}=1, P=0.0000634\right)$. These results correspond to an odds ratio of 2.48 (95\% confidence intervals 1.57-3.91) for $\mathrm{AD}$ in individuals with this $\mathrm{T}$ allele. Based on the observed allele frequency of the 

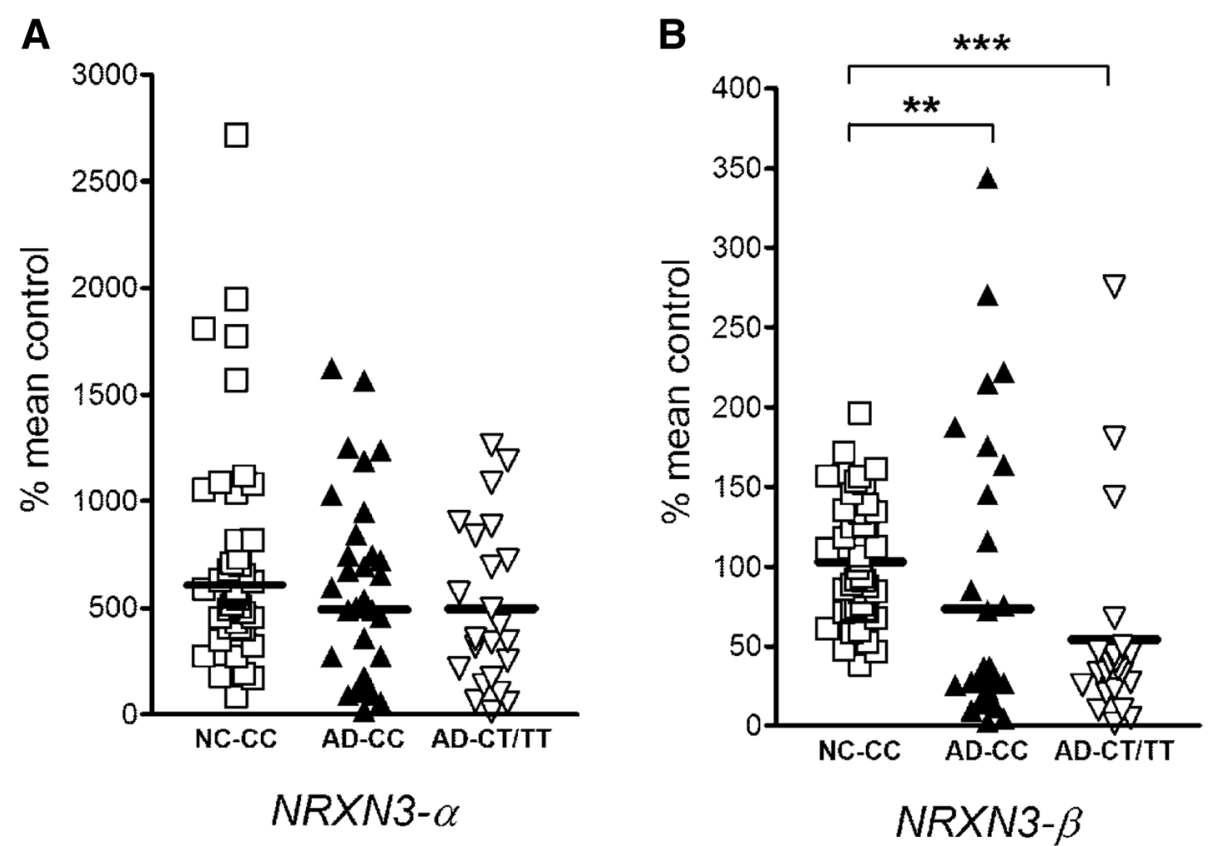

Fig. 1 a-NRXN3 (a) and $\beta-N R X N 3$ (b) mRNA expressions in the middle frontal gyrus of control individuals ( $n=44$ individuals with rs8019381 CC genotype) and AD patients ( $n=35$ individuals with rs8019381 CC genotype and $n=23$ individuals with CT or $\Pi$ genotypes). Relative levels of each mRNA expression were obtained after normalization to GAPDH. Then, percentile change is obtained respective to an average of NRXN3- $\beta$ mRNA in control individuals with CC genotype. ${ }^{* *} P<0.001$, ${ }^{* *} P<0.0001$, calculated using two-tailed Mann-Whitney tests

rs8019381 SNP, the current samples yielded the power of 0.894 for detecting nominally significant results. There was no significant effect of age on the distribution of rs8019381 genotypes in the AD group $(P=0.562$ by one-way ANOVA). The rs8019381 genotype distributions also displayed no significant deviation from Hardy-Weinberg equilibrium in either the $\mathrm{AD}$ or control groups (data not shown).

We next investigated the $A P O E$ genotypes in these samples and sought possible interactions with the effects of the NRXN3 haplotypes marked by the rs8019381 SNP (Table 2). As expected, the APOE genotype and allele frequency distributions of the AD samples differed significantly from those of the control group $\left(\chi^{2}=87.146, \mathrm{df}=5\right.$, $P=2.671 \times 10^{-17}$ and $X^{2}=92.374, \mathrm{df}=2, P=8.735 \times 10^{-21}$, respectively; Table 2 ).

When we sought interactions between the rs8019381 SNP and APOE genotypes in the AD group, the rs8019381 genotype distributions displayed significant differences between $A P O E \& 4$ non-carriers and $A P O E \varepsilon 4$ carriers $\left(\chi^{2}=8.043, \mathrm{df}=2, P=0.0179\right)$. Among AD individuals, rs8019381 TT homozygotes were found only in those who did not carry APOE $\varepsilon 4$ alleles. This difference provided significance for recessive analysis (comparing $\mathrm{CC}+\mathrm{CT}$ vs TT) of the differences between AD APOE $\varepsilon 4$ non-carriers and AD APOE \&4 carriers $\left(\chi^{2}=6.317 \mathrm{df}=\right.$ $1, P=0.012)$, though not for analyses of allele frequencies $\left(\chi^{2}=0.429, \quad \mathrm{df}=1, \quad P=0.513\right)$. These results contrasted with those in control samples, where we found that neither genotype distributions nor allele frequencies were significantly different between $A P O E \& 4$ non-carriers and $A P O E \& 4$ carriers $(P=0.428$ and 0.541 for genotype and allele comparisons, respectively).

Overall, significant associations between the rs8019381 genotypes and AD thus remained in both $A P O E \& 4$ non-carriers $(P=0.000403)$ and in $A P O E \& 4$ carriers $(P=0.00331)$. The allele frequencies for the rs8019381 SNP also differed significantly in AD vs control comparisons in both the $A P O E \& 4$ non-carriers $(P=0.00252)$ and $A P O E \& 4$ carriers $(P=0.00827)$. We also confirmed a significant effect of rs8019381 polymorphism on the AD phenotype considering for age, gender, and APOE \&4 allele $(P=0.00157$, Table 3$)$.

As anticipated for loci on distinct chromosomes, APOE (19q13) and NRXN3 (14q24) markers displayed evidence for independent segregation in these samples. Neither the genotype distribution nor allele frequency of rs8019381 SNP was associated with the APOE allele frequency among the $\mathrm{AD}$ or control groups $\left(P_{\mathrm{AD}}=0.061\right.$, $P_{\mathrm{CTL}}=0.850$ and $P_{\mathrm{AD}}=0.600, P_{\mathrm{CTL}}=0.283$ for genotypic and allelic comparisons, respectively).

Genetic variation and NRXN3 SS\#5 splice variants in AD

Since the NRXN3 haplotype tagged by rs8019381 (Fig. 3a) has been associated with altered patterns of expression of NRXN3 splice variants that encode 

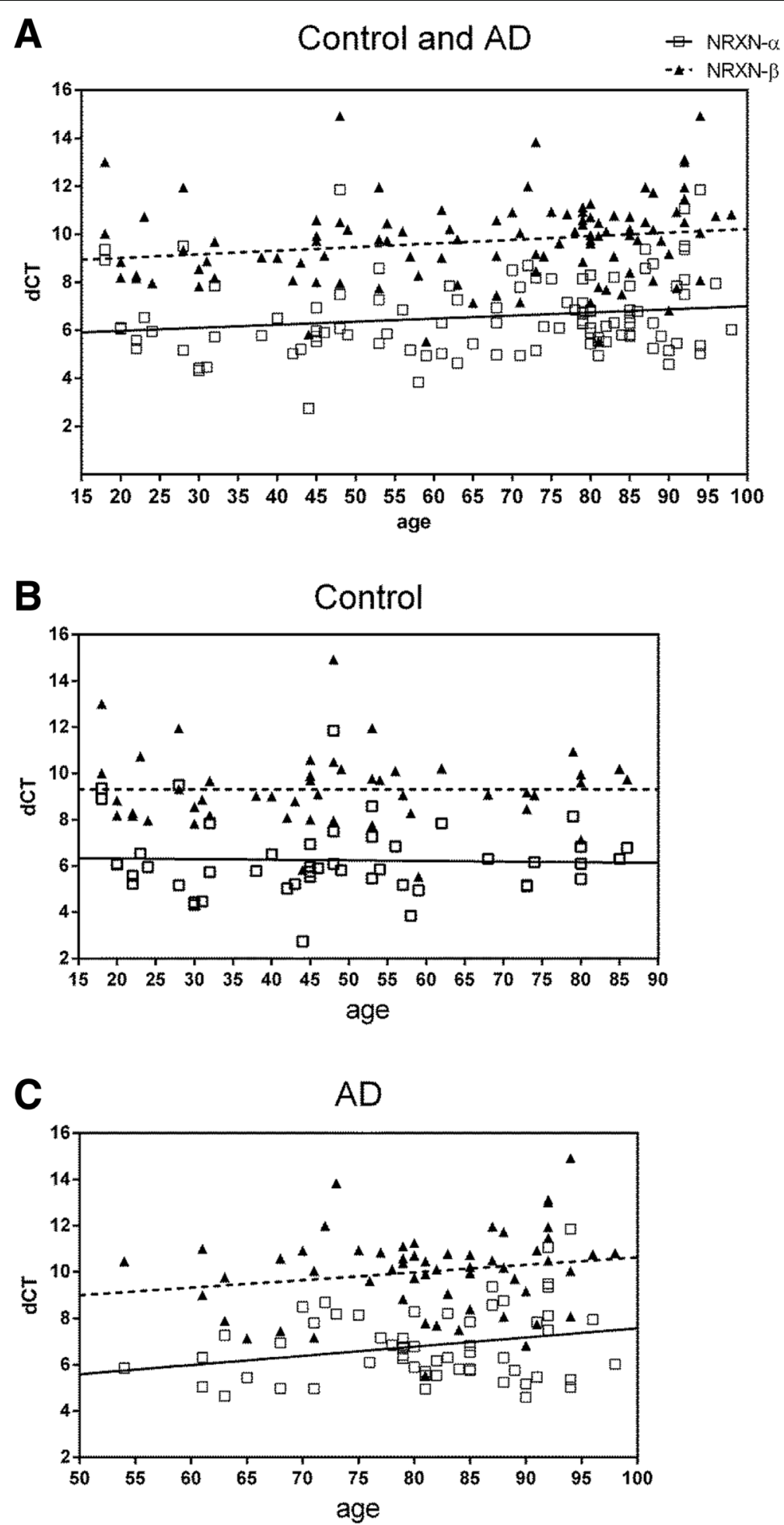

Fig. 2 a Correlation between age and either a-NRXN3 or $\beta-N R X N 3$ mRNA expression levels in the control and AD combined groups $(P=0.0473$, Spearman $r=0.193$ and $P=0.0061$, Spearman $r=0.2648$, respectively). $\mathbf{b}$ Correlation between a-NRXN3 and $\beta$-NRXN3 mRNA expression levels in the control group and age ( $P=0.787$, Spearman $r=0.040$ and $p=0.386$, Spearman $r=0.128$, respectively), and $\mathbf{c}$ in the AD group and age $\left(P=0.253\right.$, Spearman $r=0.153$ and $P=0.186$, Spearman $r=0.176$, respectively). $\Delta C_{t}$ values of each isoform expression were obtained after normalization to $C_{t}$ values of GAPDH 
Table 2 Distribution of the NRXN3 rs8019381 C/T SNP and APOE allele frequencies among the rs8019381 genotypes

\begin{tabular}{|c|c|c|c|c|c|c|c|}
\hline \multirow{2}{*}{\multicolumn{2}{|c|}{ Group }} & \multicolumn{3}{|l|}{ Genotype $^{a}$} & \multicolumn{2}{|c|}{ Allele frequency } & \multirow[t]{2}{*}{$P$ value } \\
\hline & & $\mathrm{CC}$ & $\mathrm{CT}$ & $\Pi$ & $\mathrm{C}$ & $\mathrm{T}$ & \\
\hline \multicolumn{8}{|c|}{ rs8019381 genotype and allele frequencies ${ }^{\mathrm{b}}$} \\
\hline \multicolumn{2}{|c|}{ Control $(n=336)$} & $291(0.866)$ & $43(0.128)$ & $2(0.006)$ & 0.930 & 0.070 & \multirow{2}{*}{$\begin{array}{l}\text { Genotype: } P=0.00041\left(X^{2}=15.6, d f=2\right) \\
\text { Allele: } P=0.000063\left(X^{2}=16.0, d f=1\right)\end{array}$} \\
\hline \multicolumn{2}{|c|}{$\mathrm{AD}(n=121)$} & $86(0.711)$ & $32(0.264)$ & $3(0.025)$ & 0.843 & 0.157 & \\
\hline \multicolumn{8}{|c|}{ rs8019381 genotypes among APOE $\varepsilon 4$ non-carriers and APOE $\varepsilon 4$ carriers } \\
\hline \multirow[t]{2}{*}{ Control } & $A P O E \varepsilon 4$ non-carriers & $216(0.857)$ & $35(0.139)$ & $1(0.004)$ & 0.927 & 0.073 & \multirow{4}{*}{$\begin{array}{l}A P O E \varepsilon 4 \text { non-carriers VS. } \varepsilon 4 \text { carriers in the } A D \\
\text { Genotype: } P=0.018\left(X^{2}=8.0, d f=2\right) \\
\text { Allele: } P=0.000063\left(X^{2}=0.43, d f=1\right)\end{array}$} \\
\hline & $A P O E \varepsilon 4$ carriers & $75(0.893)$ & $8(0.095)$ & $1(0.012)$ & 0.940 & 0.060 & \\
\hline \multirow[t]{2}{*}{$A D$} & $A P O E \varepsilon 4$ non-carriers & $26(0.722)$ & $7(0.195)$ & $3(0.083)$ & 0.819 & 0.181 & \\
\hline & APOE \&4 carriers & $60(0.706)$ & $25(0.294)$ & $0(0.000)$ & 0.853 & 0.147 & \\
\hline
\end{tabular}

${ }^{a}$ Number of subjects (frequency)

${ }^{b}$ rs8019381: Significant differences were found between the $A D$ and the controls in either the genotype distribution $\left(X^{2}=15.587, \mathrm{df}=2, P=0.000413\right)$ or the allele frequencies $\left(x^{2}=15.997, \mathrm{df}=1, P=0.0000634\right)$

transmembrane vs soluble isoforms, we evaluated the distributions of these isoforms in control brains, which were virtually all from individuals with $\mathrm{CC}$ haplotypes, and in frontal cortex samples of AD brains from $\mathrm{CC}$, $\mathrm{CT}$, and TT individuals. We have previously noted that the predominant NRXN3 transmembrane isoforms that arise from alternative splicing at SS\#5 are exon 22a-24b, exon $22 \mathrm{a}-24 \mathrm{c}$, and exon $22 \mathrm{a}-24 \mathrm{a}$, while the predominant soluble isoform comes from exon 22a-23a-24a. We thus assessed the levels of these four isoforms (Fig. 3b).

The most prominent result of these assays, as with studies of total NRXN3, $\alpha-N R X N 3$, and $\beta-N R X N 3$ mRNA levels, was the reduced expression that was found for most of the isoforms in the AD postmortem middle frontal gyrus (MFG), middle temporal gyrus (MTG), and hippocampus (HIP) (Fig. 3c). In comparison with one-half reduction of total NRXN3 expression in the $\mathrm{AD}$ cortex, the exon $22 \mathrm{a}-24 \mathrm{~b}$ variant that encodes the major transmembrane isoform was expressed at levels that were decreased, by $85 \%$ in $\mathrm{AD}$ subjects with either $\mathrm{CC}$ or $\mathrm{CC} / \mathrm{TT}$ genotypes $(P<0.0001$ by two-tailed Mann-Whitney tests for both comparisons) (Fig. $4 \mathrm{~b}$ ). Levels of the exon 22a-24c variant, the second major transmembrane isoform were also decreased by $56 \%$ and

Table 3 Logistic regression analysis of rs8019381 C/T SNP on the $\mathrm{AD}$ phenotype considering for age, gender, and APOE $\varepsilon 4$ allele

\begin{tabular}{lllll}
\hline \multicolumn{4}{l}{ Coefficients of bias-reduced logistic regression } \\
\hline Variable & Parameter & Standard error & Wald $X^{2}$ & $P$ value \\
\hline Intercept & -13.917 & 1.528 & -9.107 & $<0.0001$ \\
Age & 0.179 & 0.020 & 8.750 & $<0.0001$ \\
Gender & -0.051 & 0.416 & -0.123 & 0.902 \\
APOE \&4 allele & 1.691 & 0.403268658 & 4.194 & 0.000033 \\
rs8019381 genotype & 3.078 & 0.968 & 3.181 & 0.00157
\end{tabular}

${ }^{a}$ For $A P O E \varepsilon 4$ allele analyses, $\varepsilon 4$ non-carriers were coded as 0 and $A P O E \varepsilon 4$ carriers were coded as 1

${ }^{b}$ For rs8019381 genotype analyses, each SNP was coded as 0 for major allele homozygotes, 0.5 for heterozygotes, and 1 for minor allele homozygotes
$66 \%$ in $\mathrm{AD}$ patients with $\mathrm{CC}$ and with $\mathrm{CC} / \mathrm{TT}$ genotypes when compared with control $\mathrm{CC}$ individuals (Fig. 4c; $P<0.0001$ by two-tailed Mann-Whitney test for both comparisons). Overall differences in mRNA expression levels for these two transmembrane isoforms between $\mathrm{CC}$ and $\mathrm{CT} / \mathrm{TT}$ genotypes were not detected among the $\mathrm{AD}$ patients $(P=0.611$ and 0.476 by two-tailed Mann-Whitney tests, respectively).

The major soluble NRXN3 isoform, encoded by the exon 22a-23a variant mRNA was also decreased by $63 \%$ and $71 \%$ in $\mathrm{AD}$ patients with $\mathrm{CC}$ and $\mathrm{CC} / \mathrm{TT}$ genotypes when compared with those in control individuals with CC genotypes (Fig. 4d; $P<0.0001$ by two-tailed Man$\mathrm{n}$-Whitney test for both comparisons). Differences in mRNA expression levels between CC and CT/TT genotypes were not detected among the $\mathrm{AD}$ brains $(P=0.455$ by two-tailed Mann-Whitney test).

Closer examination revealed evidence for interactions between the clinical phenotype, the $\mathrm{AD}$ susceptible rs8019381 $\mathrm{T}$ allele, and expression of the exon 22a-24a mRNA that encodes a major transmembrane isoform (Fig. 4a). Expression of exon 22a-24a mRNA was decreased by $46 \%$ in $\mathrm{AD}$ patients with CT/TT genotypes when compared with those in control individuals with CC genotypes $(P=0.0002$, two-tailed Mann-Whitney tests). Within the $\mathrm{AD}$ group, exon 22a-24a mRNA expression levels were also decreased by $46 \%$ in $\mathrm{AD}$ patients with $\mathrm{CT} / \mathrm{TT}$ genotypes when compared with those with CC genotypes $(P=0.043$ by two-tailed Mann-Whitney tests). By contrast, exon 22a-24a mRNA expression levels did not differ significantly between control and $\mathrm{AD}$ samples with $\mathrm{CC}$ genotypes $(P=0.180$ by two-tailed Mann-Whitney test). These differences correlated with differences in the ratios between transmembrane and soluble isoform expression in CC vs $\mathrm{CT} / \mathrm{TT} \mathrm{AD}$ individuals, and the ratio differences reached the margin of statistical significance (Fig. 5). In $\mathrm{AD}$ patients, the ratios of transmembrane vs soluble 


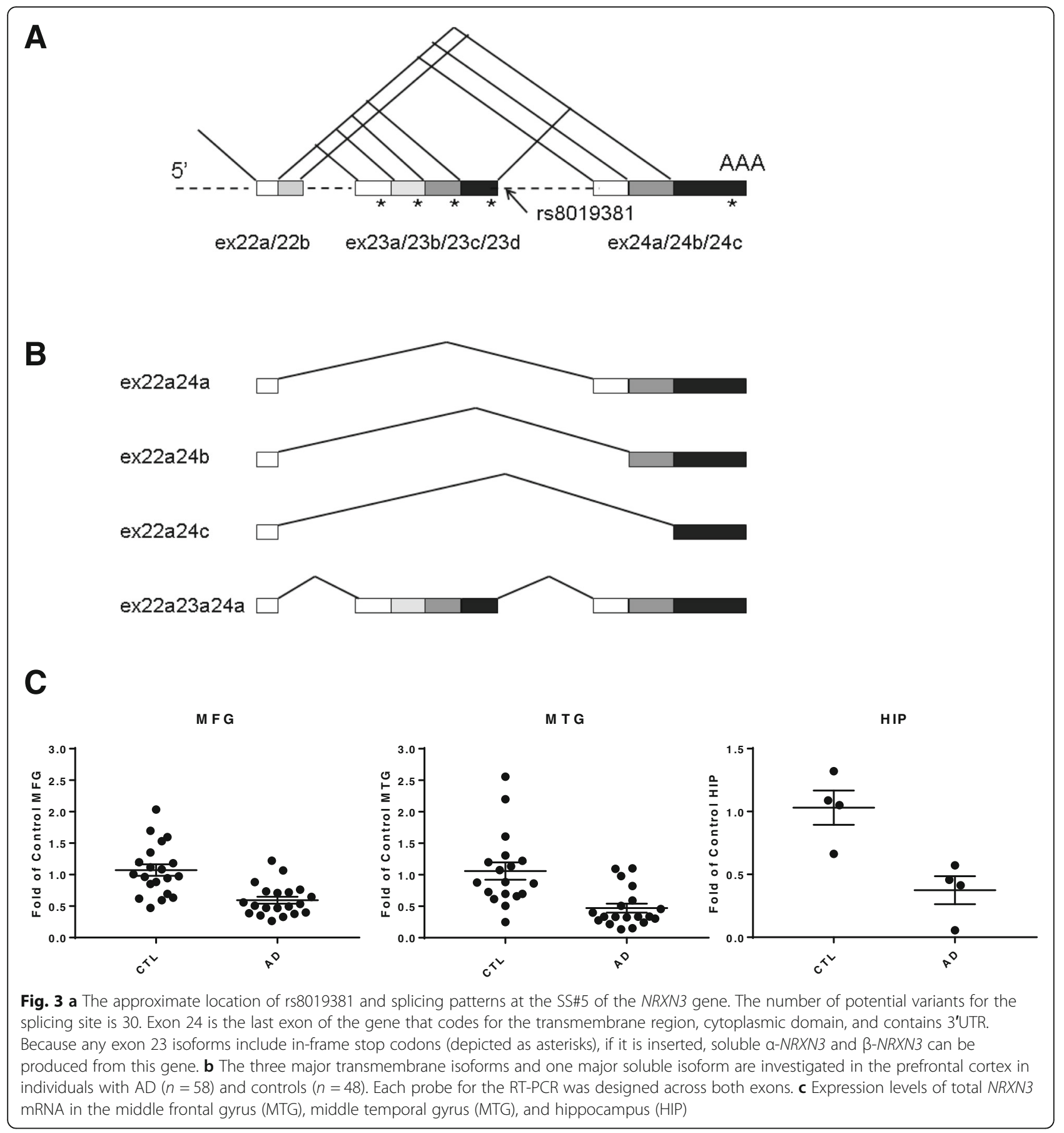

isoforms were $25 \%$ greater in $\mathrm{CT} / \mathrm{TT}$ than in $\mathrm{CC}$ subjects $(P=0.053$ by two-tailed Mann-Whitney test and $P$ $=0.044$ by unpaired $t$ test) despite that the overall ratio of the transmembrane and soluble isoforms decreased in $\mathrm{AD}$ brains. Interestingly, these ratios did not differ between $\mathrm{AD}$ patients with $\mathrm{CT} / \mathrm{TT}$ genotypes vs those in control CC individuals $(P=0.331$ by two-tailed Mann-Whitney tests).
Inverse correlation of NRXN3 with inflammasome component NLRP3 in AD brains

We carried out an ultra-sensitive RNAscope ISH assay to study the altered NRXN3 expression at cellular levels in control and $\mathrm{AD}$ postmortem brain samples that were co-hybridized and co-stained with inflammasome component NLRP3 [41] and neuron marker NEUN/RBFOX3. All NRXN3 and the majority of NLRP3 signals were 

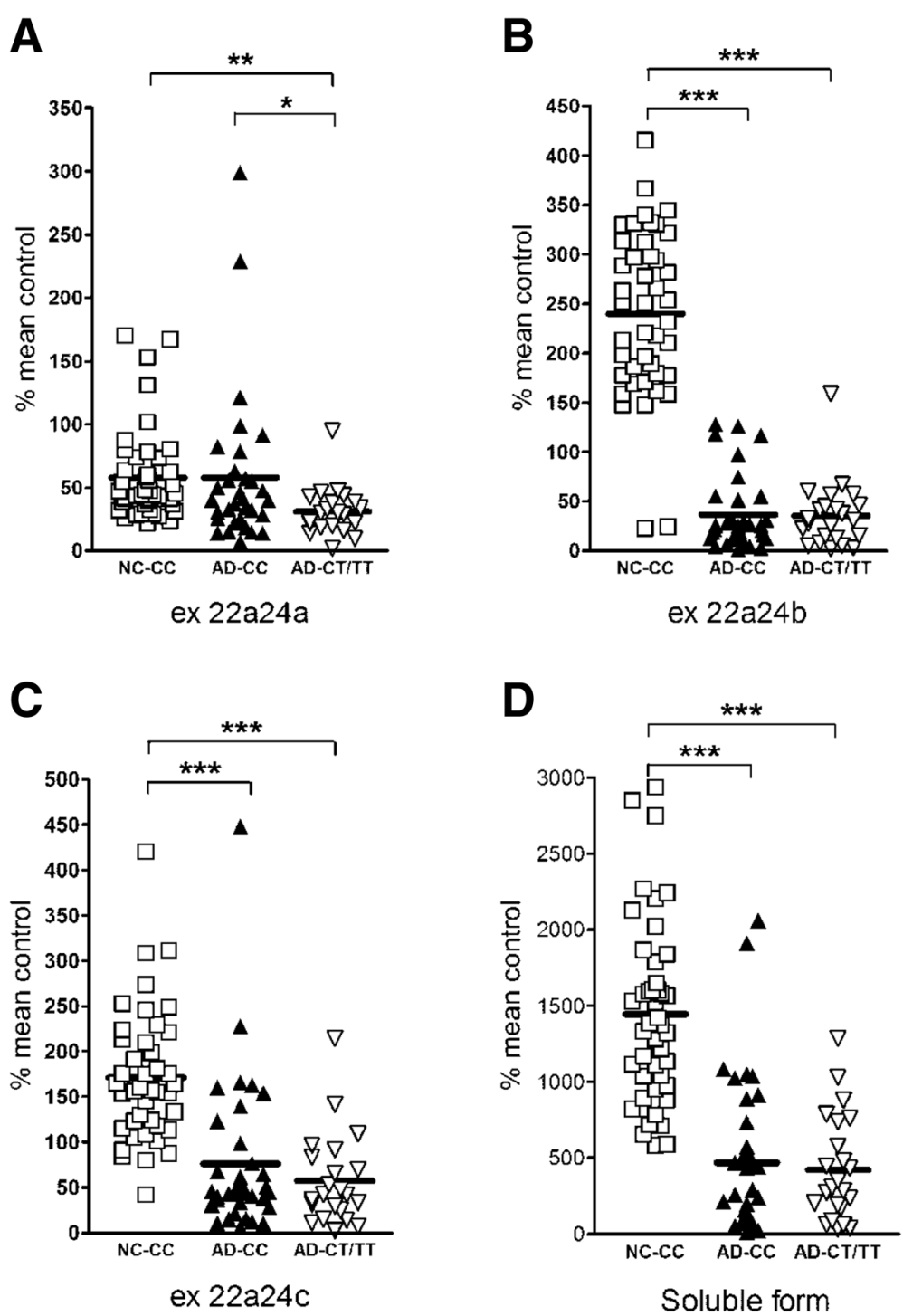

Fig. 4 a-c Expression levels of mRNAs encoding NRXN3 transmembrane isoforms (exon 22a-24a, exon 22a-24b, and exon 22a-24c variants, respectively) and $\mathbf{d}$ NRXN3 soluble isoform (exon 22a-23a variant) in the middle frontal gyrus of control individuals ( $n=44$ individuals with rs8019381 CC genotype) and AD patients ( $n=35$ individuals with rs8019381 CC genotype and $n=23$ individuals with CT or $T$ genotypes). Relative levels of each mRNA expression were obtained after normalization to GAPDH. Then, percentile change is obtained respective to an average of $\beta-N R X N 3$ mRNA in control individuals with CC genotype. ${ }^{*} P<0.05,{ }^{* *} P<0.001,{ }^{* * *} P<0.0001$, calculated using two-tailed Mann-Whitney tests

co-localized with NEUN/RBFOX3-positive neurons (Fig. 6). We found that the reduced NRXN3 mRNA was inversely correlated with the increased NLRP3 mRNA in NEUN/RBFOX3-positive neurons of the AD middle temporal gyrus (Fig. 6a-f) and hippocampus (Fig. 6g, h) samples. Two-tailed and unpaired Student's $t$ test using $\mathrm{H}$-scores that represent NRXN3 neuron expression was significantly higher than that of NLRP3 at Braak 2 stage of MTG and significantly lower at Braak 6 stage in MTG and HIP (Fig. 7a). Two-way ANOVA analysis found significant differences of $\mathrm{H}$-scores in HIP $\left(F_{1,14}=6.07\right.$; $P=0.0273)$ but not in MTG $\left(F_{1,28}=0.45 ; P=0.4515\right)$ with different Braak stages; however, the interaction of NRXN3 and NLRP3 neuron expression in MTG and HIP at different Braak stages were very significant $(P<0.0001)$. Linear regression analysis using $\mathrm{H}$-score for each Braak number $(0,1,2,4,5,6)$ found that the differences of slopes of NRXN3 and NLRP3 were significant $\left(F_{1,8}=\right.$ 11.49; $P=0.0095)$ in MTG samples. NLRP3 regression slope was significantly non-zero $\left(F_{1,4}=18.32 ; P=0.0128\right)$, and NRXN3 regression slope was not significantly non-zero $\left(F_{1,4}=0.98 ; P=0.3773\right)$. The correlation was also simulated in control $($ Braak $=0)$ and $\mathrm{AD}($ Braak $=6)$ in HIP samples. The linear regression lines for NRXN3 and 


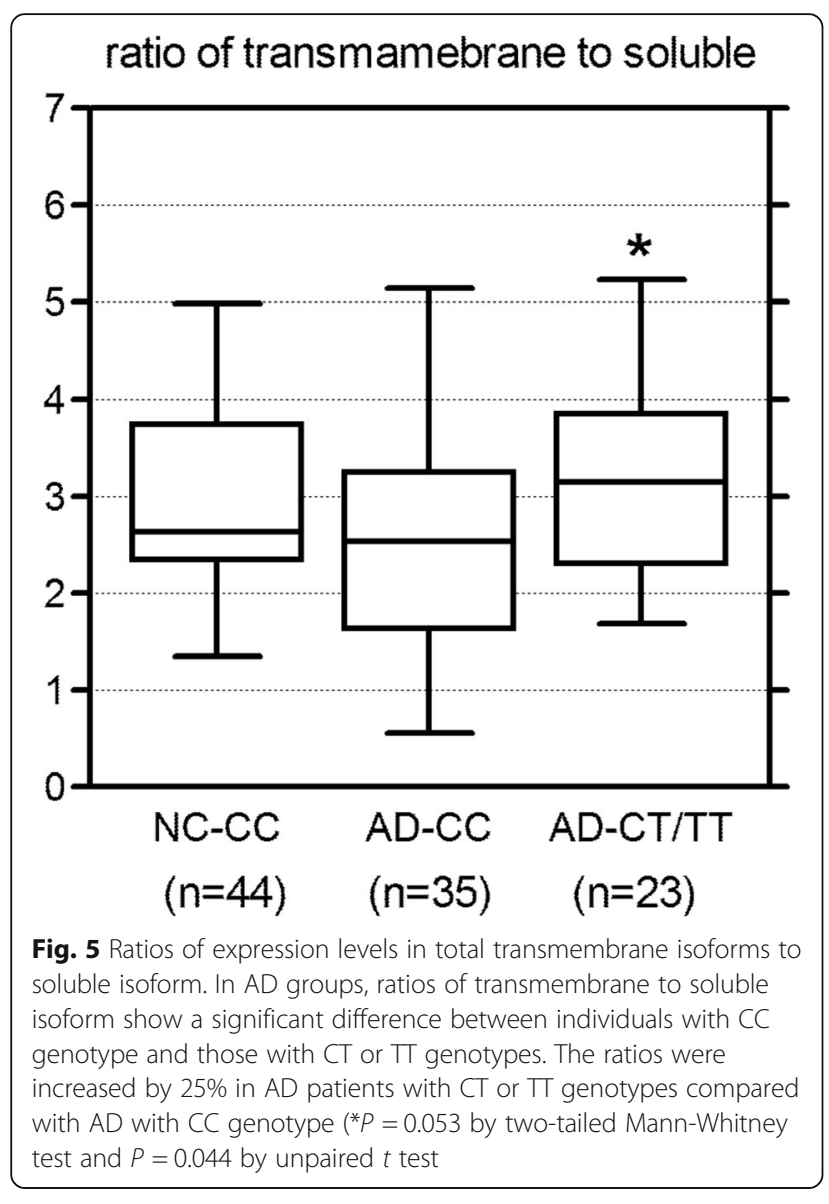

NLRP3 intersected at 2.6 and 2.1 Braak grades in MTG and HIP samples, respectively (Fig. 7b). We did not observe any significant correlation of NEUN/RBFOX3 with Braak stages (data not shown).

\section{Discussion}

We found that NRXN3 gene haplotype interacts with the $A P O E \& 4$ haplotype, and the expression and ratio of its transmembrane and soluble isoforms were reduced in AD postmortem MFG. NRXN3 mRNA level was inversely correlated with that of inflammasome component NLRP3 in MTG AD neurons. The linear regression of NRXN3 and NLRP3 signals that intersected at Braak 2.1 for HIP and Braak 2.6 for MTG might indicate differential progression of $A \beta$ fibrils in different brain regions. Previous studies by array tomography and electron microscopy find that $\mathrm{A} \beta \mathrm{O}$ forms halo at synapses that attracts $A \beta$ fibrils around damaged neurites [42-44]. The most prominent AD-associated susceptible genes and their altered expression/splicing/translation/ PTM (posttranslational modifications), such as $A P P$ and PSEN1 [23, 45], APOE and APOER2 [46], PTK2B [47], PPP3CA and PPP3R1 [48, 49], and PIN1 [50], are involved in synaptic homeostasis. Dysregulation of presynaptic NRXN3 might be an early event that triggers synaptic calcium dyshomeostasis and let $\mathrm{A} \beta \mathrm{O}$ invasion at synapses. Subsequent dystrophic neurites and dysfunctional synapses stimulate $N L R P 3 /$ caspase- 1 and calcineurin/caspase- 3 pathways that activate interleukin- $1 \beta$ and interleukin-18 [51, 52] and cause mitochondria impairment and apoptosis [53], respectively. A $\beta$ fibrils are at their peak when AD symptom just appears [54], and NRXN3 and NLRP3 expression trajectories might serve as early diagnosis and therapeutic targets at early Braak 2-3 stages.

NRXN3 SNP rs8019381 was found to contribute to AD susceptibility. There is no information available for rs8019381 in previously reported genome-wide association studies for $\operatorname{AD}[3,55,56]$ because of the relatively small haplotype block $(14 \mathrm{~kb})$ in the study. While no genomic markers that display strong linkage disequilibrium with rs8019381 are identified in the Translational Genomic Research Institute (TGen) datasets [56], we identified rs2067730 that lies about $6 \mathrm{~kb} \mathrm{5}$ ' to rs8019381 in genome-wide association studies of clinically diagnosed AD vs control subjects of European ancestries who were recruited from Canadian memory clinics [55]. Interestingly, like NRXN3 rs801938, rs2067730 displays association with $\mathrm{AD}$ in this sample and appears to interact with the $A P O E$ genotype $(P=0.027)$.

The magnitude of rs8019381 association suggests an odds ratio of 2.48 , with a broad $95 \%$ confidence interval that encompasses 1.6-3.9. While this effect is much less than the large, oligogenic influence of $A P O E$ haplotypes on AD vulnerability, it is larger than many of the effects of other proposed polygenic variants listed in systematic meta-analysis presented on the AlzGene database [57] or in two genome-wide association datasets that compare AD vs control samples [3, 55, 56]. The effects of the NRXN3 haplotype may be even larger in individuals with specific $A P O E$ haplotypes. Both the current dataset and data reported by Li et al [55] provide evidence for significant interactions among $A P O E$ haplotypes and 3' NRXN3 haplotypes in AD.

The reduced expression of total $N R X N 3, \alpha-N R X N 3$, and $\beta-N R X N 3$ in samples of the cerebral cortex and hippocampus from pathologically confirmed AD and control brains formed the initial basis for implicating NRXN3 in AD. These findings were accompanied by a significant reduction of ratios between transmembrane and soluble isoforms in AD individuals with rs8019381 CT or TT genotypes. These observations support the hypothesis that reduction of NRXN3 transmembrane isoform alters synapse homeostasis, reduces neurotransmitter release, and promotes $\mathrm{A} \beta$ oligomerization and $A P O E$ dysfunction in synaptic degeneration [7, 58]. Alternatively, the altered ratio might differentially interact with alternatively spliced isoforms of $A P P$, causing increased $A \beta$ production [59]. 


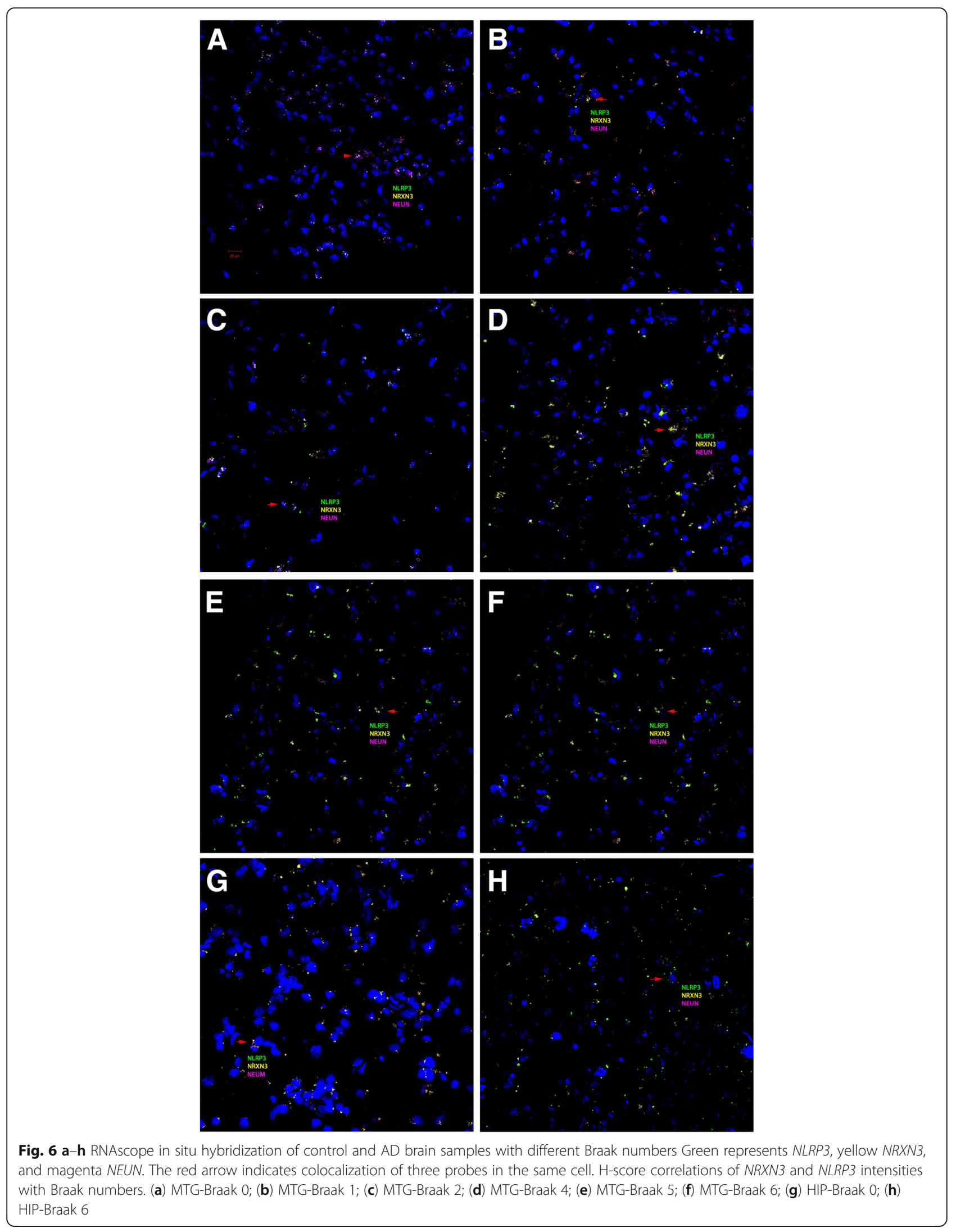




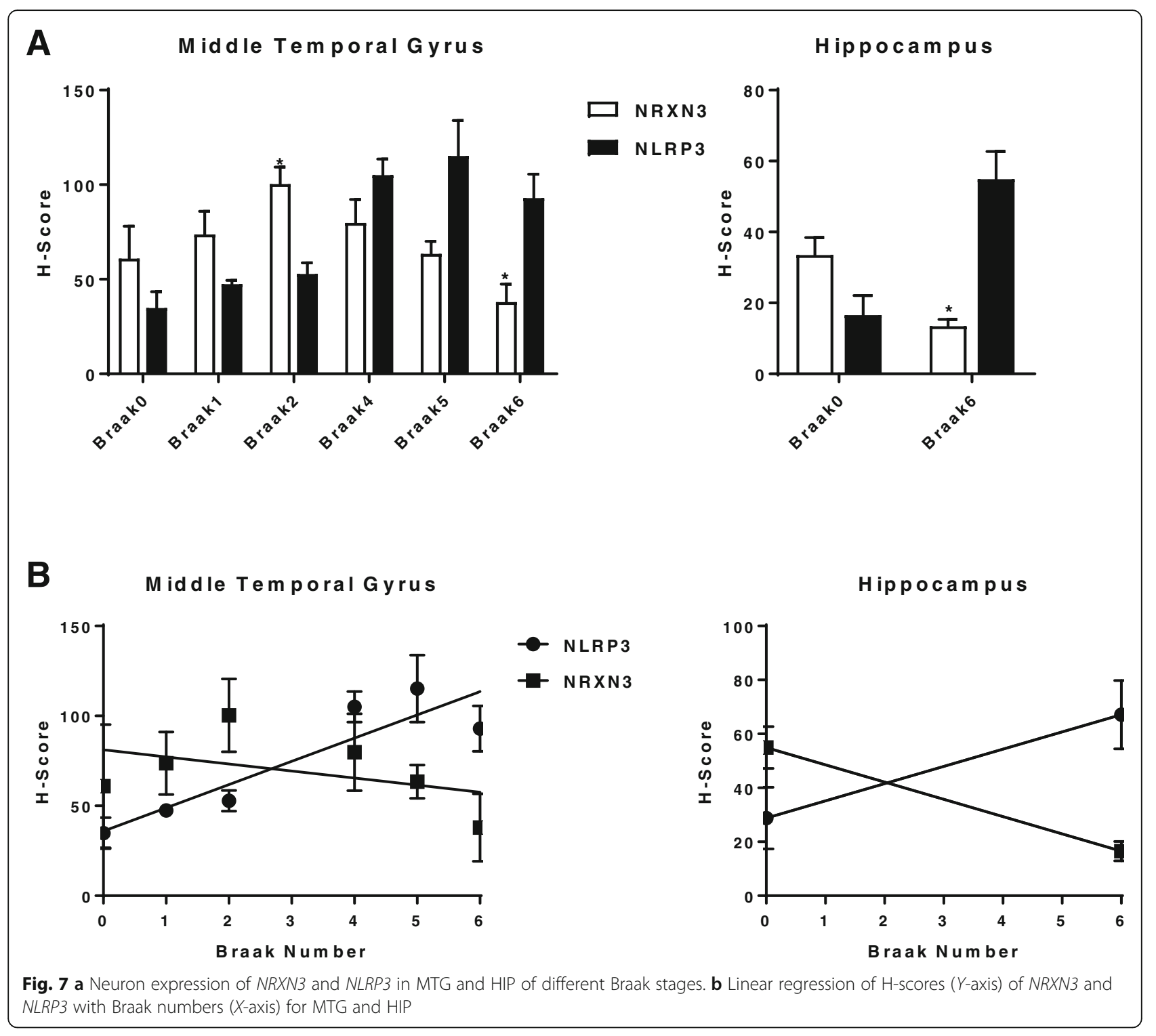

The associated NRXN3 SNP rs8019381 is located at the junction of exon 23's splicing donor site (23 base pairs downstream from the 3 ' of exon 23), within a region that might alter splicing efficiency. The NRXN3 haplotype studied here is likely to be different from other ethnic samples. The rs8019381 "T" allele frequency $(0.07)$ of the control samples reported here (based on genotypes from 672 chromosomes) is similar to values obtained in unselected Europeans and European-Americans available $(0.094$ based on genotypes from 224 chromosomes) from dbSNP. African Yoruban rs8019381 frequency (0.198) is (based on genotypes of 180 chromosomes) higher than European population, and East Asian rs8019381 frequency is much lower than European and African populations, with none of the " $\mathrm{T}$ " allele detected in Chinese (based on genotypes of 90 chromosomes) and 0.006 detected in Japanese (based on genotypes of 172 chromosomes) HapMap samples. Additional studies will be necessary to identify more informative NRXN3 rs8019381 for use in individuals with non-European heritage. Much of the evidence presented here provides an increased focus on the role of synaptic pathology in AD. Synapse losses can be documented with the first clear-cut evidence for dementia that are accompanied by synaptic toxicities conferred by $A P P$ [60] and $A P O E$ mutations [61]. The evidence in the current report suggests that $\mathrm{A} \beta$ and $A P O E$ synaptic pathologies are likely to interact with allele-specific alterations in gene expression of NRXN3 transmembrane and soluble isoforms.

An astronomical number of synapses derived from about 86 billion human brain neurons [62] are dynamic 
throughout the human life span, and their damage precedes neuron death due to $A \beta$ oligomer $(A \beta O)$ toxicity in $\mathrm{AD}[18,63]$. Substantial microscopic $\mathrm{A} \beta$ plaques are observed in old adult brains with intact cognition function [6]; however, nano-synaptic-space distribution of $A \beta O$ is less known and neurexin complexes are known partners of $A \beta$ [8]. Complex neurexin alternative splicing codes define synaptic specificity, strength, plasticity $[15,31]$, and vulnerability toward $\mathrm{A} \beta \mathrm{O}$ [64]. The trans-synaptic anterograde and retrograde signaling of the neurexin-neuroligin-endocannabinoid system $[13,31,65,66]$ provides an attractive pathway for $\mathrm{AD}$ therapeutic development. Modulation of presynaptic and postsynaptic endocannabinoid tone through CB1R [67] and CB2R [68, 69], respectively, by their specific ligands might reduce neuron inflammasome and shift neurexin-neuroligin alternative splicing repertoire toward heathy synapses and reverse cognitive decline during aging [70, 71]. Neurexin peptides are significantly elevated in cerebrospinal fluid (CSF) of individuals with mild cognitive impairment (MCI), especially in patients with MCI progressing to AD dementia [72, 73]. Conceptually, targeted tryptic peptide panels of specific neurexin isoforms will improve CSF early diagnosis for pre-symptomatic AD. Screening of effective neurexin and cannabinoid receptor ligands $[66,74]$ and behavioral modulation of mental activities and nutrition intakes [75] might help to improve synaptic health and prevent cognitive decline 10 years or more before $\mathrm{AD}$ symptom appearance.

\section{Conclusion}

NRXN3 rs8019381 SNP located at SS\#5 splicing site was found to contribute to $\mathrm{AD}$ susceptibility and interact with the $A P O E \& 4$ haplotype. The altered expressions of NRXN3 transmembrane and soluble isoforms were further reduced in susceptible rs8019381 heterozygous and homozygous alleles (CT or TT) in the AD postmortem cortex. The reduced NRXN3 expression was inversely correlated with the increase of inflammasome component NLRP3 expression in NEUN/RBFOX3-positive neurons in the $\mathrm{AD}$ brain.

\footnotetext{
Abbreviations

AD: Alzheimer's disease; A $\beta$ : Amyloid beta; $A \beta O$ : Amyloid beta oligomer; CSF: Cerebral spinal fluid; HIP: Hippocampus; HWE: Hardy-Weinberg equilibrium; LNS: Lamin-neurexin-sex hormone-binding globulin domains; MCl: Mild cognitive impairment; MFG: Middle frontal gyrus; MTG: Middle temporal gyrus; NFT: Neurofibrillary tangles; PCR-RFLP: PCR and restriction fragment length polymorphism; PDZ: PSD95-Dlg1-Zo1 domain; PMI: Postmortem interval; PTM: Posttranslational modification; RT-

PCR: Reverse transcription polymerase chain reaction; SNP: Single nucleotide polymorphism; SS\#5: Splicing site 5
}

\section{Acknowledgements}

The authors acknowledge human DNA samples provided by Maryland Brain Bank (UMD) and the Collaborative Study on the Genetics of Alcoholism (COGA).

\section{Funding}

Intramural Research Programs (AG-000291-11) of NIA/NIH and the Johns Hopkins University Alzheimer's Disease Research Center (NIH P50AG05146)

Availability of data and materials

Data available on request from the author.

\section{Authors' contributions}

$\mathrm{QRL}, \mathrm{AH}$, and JME were responsible for the conception and design of the study. $\mathrm{AH}$ and $\mathrm{QRL}$ carried out the experiments and were responsible for the analysis, interpretation of the data, and drafting of the manuscript. DLL performed in the cryostat sectioning of the postmortem brain samples and RNAscope in situ hybridization. OP and JCT provided the postmortem AD and control brain samples with Braak staining stages and gave invaluable advice for the manuscript. All authors read and approved the final manuscript.

\section{Ethics approval and consent to participate}

The experiments on the postmortem brain tissues ware approved by John Hopkins Medicine Institutional Review Board (https://

www.hopkinsmedicine.org/institutional_review_board/index.html).

\section{Consent for publication}

Publication clearance by $\mathrm{NIA} / \mathrm{NIH}$.

\section{Competing interests}

The authors declare that they have no competing interests.

\section{Publisher's Note}

Springer Nature remains neutral with regard to jurisdictional claims in published maps and institutional affiliations.

\section{Author details}

${ }^{1}$ Department of Psychiatry, Kobe University Graduate School of Medicine, 7-5-1 Kusunoki-Cho, Chuo-Ku, Kobe 650-0017, Japan. ²Departments of Pathology, Neuropathology Division, Johns Hopkins University School of Medicine, 600 North Wolfe Street, Baltimore, MD 21205, USA. ${ }^{3}$ Lab of Clinical Investigation, NIA-NIH, 251 Bayview Blvd, Baltimore, MD 21224, USA.

Received: 17 September 2018 Accepted: 17 February 2019

Published online: 21 March 2019

References

1. Kim SH, Tang YP, Sisodia SS. Abeta star: a light onto synaptic dysfunction? Nat Med. 2006:12(7):760-1 discussion 761.

2. Aoto J, Martinelli DC, Malenka RC, Tabuchi K, Sudhof TC. Presynaptic neurexin-3 alternative splicing trans-synaptically controls postsynaptic AMPA receptor trafficking. Cell. 2013;154(1):75-88.

3. Coon KD, Myers AJ, Craig DW, Webster JA, Pearson JV, Lince DH, Zismann $V L$, Beach TG, Leung D, Bryden L, et al. A high-density whole-genome association study reveals that APOE is the major susceptibility gene for sporadic late-onset Alzheimer's disease. J Clin Psychiatry. 2007;68(4):613-8.

4. Elman JA, Oh H, Madison CM, Baker SL, Vogel JW, Marks SM, Crowley S, O'Neil JP, Jagust WJ. Neural compensation in older people with brain amyloid-beta deposition. Nat Neurosci. 2014;17(10):1316-8.

5. Pletnikova O, Rudow GL, Hyde TM, Kleinman JE, Ali SZ, Bharadwaj R, Gangadeen S, Crain BJ, Fowler DR, Rubio Al, et al. Alzheimer lesions in the autopsied brains of people 30 to 50 years of age. Cogn Behav Neurol. 2015; 28(3):144-52.

6. lacono D, Resnick SM, O'Brien R, Zonderman AB, An Y, Pletnikova O, Rudow G, Crain B, Troncoso JC. Mild cognitive impairment and asymptomatic Alzheimer disease subjects: equivalent beta-amyloid and tau loads with divergent cognitive outcomes. J Neuropathol Exp Neurol. 2014;73(4):295-304.

7. Priller C, Bauer T, Mitteregger G, Krebs B, Kretzschmar HA, Herms J. Synapse formation and function is modulated by the amyloid precursor protein. J Neurosci. 2006;26(27):7212-21.

8. Viola KL, Velasco PT, Klein WL. Why Alzheimer's is a disease of memory: the attack on synapses by a beta oligomers (ADDLs). J Nutr Health Aging. 2008; 12(1):51S-7S. 
9. Ushkaryov YA, Petrenko AG, Geppert M, Sudhof TC. Neurexins: synaptic cell surface proteins related to the alpha-latrotoxin receptor and laminin. Science. 1992;257(5066):50-6.

10. Li CY, Liu QR, Zhang PW, Li XM, Wei L, Uhl GR. OKCAM: an ontology-based, human-centered knowledgebase for cell adhesion molecules. Nucleic Acids Res. 2009;37(Database issue):D251-60.

11. Missler M, Sudhof TC. Neurexins: three genes and 1001 products. Trends Genet. 1998;14(1):20-6.

12. Sudhof TC. Neuroligins and neurexins link synaptic function to cognitive disease. Nature. 2008;455(7215):903-11.

13. Missler M, Zhang W, Rohlmann A, Kattenstroth G, Hammer RE, Gottmann K, Sudhof TC. Alpha-neurexins couple Ca2+ channels to synaptic vesicle exocytosis. Nature. 2003;423(6943):939-48.

14. Rudenko G. Dynamic control of synaptic adhesion and organizing molecules in synaptic plasticity. Neural Plast. 2017;2017:6526151.

15. Sudhof TC. Synaptic neurexin complexes: a molecular code for the logic of neural circuits. Cell. 2017;171(4):745-69.

16. Biederer T, Sudhof TC. Mints as adaptors. Direct binding to neurexins and recruitment of munc18. J Biol Chem. 2000;275(51):39803-6.

17. Hata Y, Butz S, Sudhof TC. CASK: a novel dlg/PSD95 homolog with an Nterminal calmodulin-dependent protein kinase domain identified by interaction with neurexins. J Neurosci. 1996;16(8):2488-94.

18. Naito $Y$, Tanabe $Y$, Lee AK, Hamel E, Takahashi H. Amyloid-beta oligomers interact with neurexin and diminish neurexin-mediated excitatory presynaptic organization. Sci Rep. 2017;7:42548.

19. Miller CC, McLoughlin DM, Lau KF, Tennant ME, Rogelj B. The X11 proteins, Abeta production and Alzheimer's disease. Trends Neurosci. 2006;29(5):280-5.

20. Hishimoto A, Liu QR, Drgon T, Pletnikova O, Walther D, Zhu XG, Troncoso $J C$, Uhl GR. Neurexin 3 polymorphisms are associated with alcohol dependence and altered expression of specific isoforms. Hum Mol Genet. 2007;16(23):2880-91

21. Ushkaryov YA, Sudhof TC. Neurexin III alpha: extensive alternative splicing generates membrane-bound and soluble forms. Proc Natl Acad Sci U S A. 1993;90(14):6410-4.

22. Anderson GR, Aoto J, Tabuchi K, Foldy C, Covy J, Yee AX, Wu D, Lee SJ, Chen L, Malenka RC, et al. beta-Neurexins control neural circuits by regulating synaptic endocannabinoid signaling. Cell. 2015;162(3):593-606.

23. Bot N, Schweizer C, Ben Halima S, Fraering PC. Processing of the synaptic cell adhesion molecule neurexin-3beta by Alzheimer disease alpha- and gamma-secretases. J Biol Chem. 2011;286(4):2762-73.

24. Alarcon M, Abrahams BS, Stone JL, Duvall JA, Perederiy JV, Bomar JM, Sebat J, Wigler $\mathrm{M}$, Martin $\mathrm{CL}$, Ledbetter $\mathrm{DH}$, et al. Linkage, association, and geneexpression analyses identify CNTNAP2 as an autism-susceptibility gene. Am J Hum Genet. 2008;82(1):150-9.

25. Arking DE, Cutler DJ, Brune CW, Teslovich TM, West K, Ikeda M, Rea A, Guy $M$, Lin $S$, Cook EH, et al. A common genetic variant in the neurexin superfamily member CNTNAP2 increases familial risk of autism. Am J Hum Genet. 2008;82(1):160-4.

26. Kim HG, Kishikawa S, Higgins AW, Seong IS, Donovan DJ, Shen Y, Lally E, Weiss LA, Najm J, Kutsche K, et al. Disruption of neurexin 1 associated with autism spectrum disorder. Am J Hum Genet. 2008:82(1):199-207.

27. Bierut LJ, Madden PA, Breslau N, Johnson EO, Hatsukami D, Pomerleau OF, Swan GE, Rutter J, Bertelsen S, Fox L, et al. Novel genes identified in a highdensity genome wide association study for nicotine dependence. Hum Mol Genet. 2007:16(1):24-35.

28. Lachman HM, Fann CS, Bartzis M, Evgrafov OV, Rosenthal RN, Nunes EV, Miner C, Santana M, Gaffney J, Riddick A, et al. Genomewide suggestive linkage of opioid dependence to chromosome 14q. Hum Mol Genet. 2007;16(11):1327-34

29. Kirov G, Gumus D, Chen W, Norton N, Georgieva L, Sari M, O'Donovan MC Erdogan F, Owen MJ, Ropers $\mathrm{HH}$, et al. Comparative genome hybridization suggests a role for NRXN1 and APBA2 in schizophrenia. Hum Mol Genet. 2008;17(3):458-65.

30. Rujescu D, Ingason A, Cichon S, Pietilainen OP, Barnes MR, Toulopoulou T, Picchioni M, Vassos E, Ettinger U, Bramon E, et al. Disruption of the neurexin 1 gene is associated with schizophrenia. Hum Mol Genet. 2009;18(5):988-96.

31. Aoto J, Foldy C, Ilcus SM, Tabuchi K, Sudhof TC. Distinct circuit-dependent functions of presynaptic neurexin-3 at GABAergic and glutamatergic synapses. Nat Neurosci. 2015;18(7):997-1007.

32. Zheng JJ, Li WX, Liu JQ, Guo YC, Wang Q, Li GH, Dai SX, Huang JF. Low expression of aging-related NRXN3 is associated with Alzheimer disease: a systematic review and meta-analysis. Medicine (Baltimore). 2018;97(28):e11343.
33. Braak H, Braak E. Neuropathological staging of Alzheimer-related changes. Acta Neuropathol. 1991:82(4):239-59.

34. Bobinski M, de Leon MJ, Wegiel J, Desanti S, Convit A, Saint Louis LA, Rusinek $\mathrm{H}$, Wisniewski HM. The histological validation of post mortem magnetic resonance imaging-determined hippocampal volume in Alzheimer's disease. Neuroscience. 2000;95(3):721-5.

35. Troncoso JC, Cataldo AM, Nixon RA, Barnett JL, Lee MK, Checler F, Fowler DR, Smialek JE, Crain B, Martin L, et al. Neuropathology of preclinical and clinical late-onset Alzheimer's disease. Ann Neurol. 1998;43(5):673-6.

36. Edenberg HJ, Bierut LJ, Boyce P, Cao M, Cawley S, Chiles R, Doheny KF, Hansen $M$, Hinrichs $T$, Jones $K$, et al. Description of the data from the Collaborative Study on the Genetics of Alcoholism (COGA) and singlenucleotide polymorphism genotyping for Genetic Analysis Workshop 14. BMC Genet. 2005;6(Suppl 1):S2.

37. Liu QR, Drgon T, Johnson C, Walther D, Hess J, Uhl GR. Addiction molecular genetics: 639,401 SNP whole genome association identifies many "cell adhesion" genes. Am J Med Genet B Neuropsychiatr Genet. 2006;141B(8):918-25.

38. Wenham PR, Price WH, Blandell G. Apolipoprotein E genotyping by onestage PCR. Lancet. 1991;337(8750):1158-9.

39. Doyle ME, Fiori JL, Gonzalez Mariscal I, Liu QR, Goodstein E, Yang H, Shin YK, Santa-Cruz Calvo S, Indig FE, Egan JM. Insulin is transcribed and translated in mammalian taste bud cells. Endocrinology. 2018;159(9):3331-9.

40. Dupont WD, Plummer WD Jr. Power and sample size calculations for studies involving linear regression. Control Clin Trials. 1998;19(6):589-601.

41. Heneka MT, Kummer MP, Stutz A, Delekate A, Schwartz S, Vieira-Saecker A, Griep A, Axt D, Remus A, Tzeng TC, et al. NLRP3 is activated in Alzheimer's disease and contributes to pathology in APP/PS1 mice. Nature. 2013; 493(7434):674-8.

42. O'Rourke NA, Weiler NC, Micheva KD, Smith SJ. Deep molecular diversity of mammalian synapses: why it matters and how to measure it. Nat Rev Neurosci. 2012;13(6):365-79.

43. Spires-Jones TL, Hyman BT. The intersection of amyloid beta and tau at synapses in Alzheimer's disease. Neuron. 2014;82(4):756-71.

44. Kay KR, Smith C, Wright AK, Serrano-Pozo A, Pooler AM, Koffie R, Bastin ME, Bak $\mathrm{TH}$, Abrahams S, Kopeikina KJ, et al. Studying synapses in human brain with array tomography and electron microscopy. Nat Protoc. 2013:8(7):1366-80.

45. Richter MC, Ludewig S, Winschel A, Abel T, Bold C, Salzburger LR, Klein S, Han K, Weyer SW, Fritz AK, et al. Distinct in vivo roles of secreted APP ectodomain variants APPsalpha and APPsbeta in regulation of spine density, synaptic plasticity, and cognition. EMBO J. 2018;37(11). https://doi.org/10. 15252/embj.201798335.

46. Lane-Donovan C, Herz J. ApoE, ApoE receptors, and the synapse in Alzheimer's disease. Trends Endocrinol Metab. 2017;28(4):273-84.

47. Salazar SV, Cox TO, Lee S, Brody AH, Chyung AS, Haas LT, Strittmatter SM. Alzheimer's disease risk factor Pyk2 mediates amyloid-beta-induced synaptic dysfunction and loss. J Neurosci. 2019;39(4):758-72.

48. Chiocco MJ, Zhu X, Walther D, Pletnikova O, Troncoso JC, Uhl GR, Liu QR. Fine mapping of calcineurin (PPP3CA) gene reveals novel alternative splicing patterns, association of 5'UTR trinucleotide repeat with addiction vulnerability, and differential isoform expression in Alzheimer's disease. Subst Use Misuse. 2010;45(11):1809-26.

49. Cruchaga C, Kauwe JS, Mayo K, Spiegel N, Bertelsen S, Nowotny P, Shah AR, Abraham R, Hollingworth P, Harold D, et al. SNPs associated with cerebrospinal fluid phospho-tau levels influence rate of decline in Alzheimer's disease. PLoS Genet. 2010;6(9):e1001101.

50. Stallings NR, O'Neal MA, Hu J, Kavalali ET, Bezprozvanny I, Malter JS. Pin1 mediates Abeta42-induced dendritic spine loss. Sci Signal. 2018;11(522). https://doi.org/10.1126/scisignal.aap8734.

51. Levy M, Thaiss CA, Elinav E. Taming the inflammasome. Nat Med. 2015;21(3): $213-5$.

52. Supnet C, Bezprozvanny I. Neuronal calcium signaling, mitochondrial dysfunction, and Alzheimer's disease. J Alzheimers Dis. 2010;20(Suppl 2):S487-98.

53. Wu HY, Hudry E, Hashimoto T, Kuchibhotla K, Rozkalne A, Fan Z, SpiresJones T, Xie H, Arbel-Ornath M, Grosskreutz CL, et al. Amyloid beta induces the morphological neurodegenerative triad of spine loss, dendritic simplification, and neuritic dystrophies through calcineurin activation. J Neurosci. 2010;30(7):2636-49.

54. Holtzman DM, Morris JC, Goate AM. Alzheimer's disease: the challenge of the second century. Sci Transl Med. 2011;3(77):77sr71.

55. Li H, Wetten S, Li L, St Jean PL, Upmanyu R, Surh L, Hosford D, Barnes MR, Briley JD, Borrie M, et al. Candidate single-nucleotide polymorphisms from a 
genomewide association study of Alzheimer disease. Arch Neurol. 2008;65(1): 45-53.

56. Reiman EM, Webster JA, Myers AJ, Hardy J, Dunckley T, Zismann VL, Joshipura KD, Pearson JV, Hu-Lince D, Huentelman MJ, et al. GAB2 alleles modify Alzheimer's risk in APOE epsilon4 carriers. Neuron. 2007;54(5):713-20.

57. Bertram L, McQueen MB, Mullin K, Blacker D, Tanzi RE. Systematic metaanalyses of Alzheimer disease genetic association studies: the AlzGene database. Nat Genet. 2007;39(1):17-23.

58. Chung WS, Verghese PB, Chakraborty C, Joung J, Hyman BT, Ulrich JD, Holtzman DM, Barres BA. Novel allele-dependent role for APOE in controlling the rate of synapse pruning by astrocytes. Proc Natl Acad Sci U S A. 2016;113(36):10186-91.

59. Octave JN. The amyloid peptide precursor in Alzheimer's disease. Acta Neurol Belg. 1995;95(4):197-209.

60. Kero M, Paetau A, Polvikoski T, Tanskanen M, Sulkava R, Jansson L, Myllykangas L, Tienari PJ. Amyloid precursor protein (APP) A673T mutation in the elderly Finnish population. Neurobiol Aging. 2013;34(5):1518 e1511-1513.

61. Terry RD. Cell death or synaptic loss in Alzheimer disease. J Neuropathol Exp Neurol. 2000;59(12):1118-9.

62. Azevedo FA, Carvalho LR, Grinberg LT, Farfel JM, Ferretti RE, Leite RE, Jacob Filho W, Lent R, Herculano-Houzel S. Equal numbers of neuronal and nonneuronal cells make the human brain an isometrically scaled-up primate brain. J Comp Neurol. 2009;513(5):532-41

63. Brito-Moreira J, Lourenco MV, Oliveira MM, Ribeiro FC, Ledo JH, Diniz LP, Vital JFS, Magdesian MH, Melo HM, Barros-Aragao F, et al. Interaction of amyloid-beta (Abeta) oligomers with neurexin 2alpha and neuroligin 1 mediates synapse damage and memory loss in mice. J Biol Chem. 2017; 292(18):7327-37.

64. Quinn DP, Kolar A, Wigerius M, Gomm-Kolisko RN, Atwi H, Fawcett JP, Krueger SR. Pan-neurexin perturbation results in compromised synapse stability and a reduction in readily releasable synaptic vesicle pool size. Sci Rep. 2017;7:42920.

65. Wang H. Endocannabinoid mediates excitatory synaptic function of betaneurexins. Commentary: beta-neurexins control neural circuits by regulating synaptic endocannabinoid signaling. Front Neurosci. 2016;10:203.

66. Schenk U, Verderio C, Benfenati F, Matteoli M. Regulated delivery of AMPA receptor subunits to the presynaptic membrane. EMBO J. 2003;22(3):558-68

67. Han X, He Y, Bi GH, Zhang HY, Song R, Liu QR, Egan JM, Gardner EL, Li J, Xi ZX. CB1 receptor activation on VgluT2-expressing glutamatergic neurons underlies delta(9)-tetrahydrocannabinol (delta(9)-THC)-induced aversive effects in mice. Sci Rep. 2017;7(1):12315.

68. Liu QR, Canseco-Alba A, Zhang HY, Tagliaferro P, Chung M, Dennis E, Sanabria B, Schanz N, Escosteguy-Neto JC, Ishiguro H, et al. Cannabinoid type 2 receptors in dopamine neurons inhibits psychomotor behaviors, alters anxiety, depression and alcohol preference. Sci Rep. 2017;7(1):17410.

69. Brusco A, Tagliaferro P, Saez T, Onaivi ES. Postsynaptic localization of CB2 cannabinoid receptors in the rat hippocampus. Synapse. 2008;62(12):944-9.

70. Bilkei-Gorzo A, Albayram O, Draffehn A, Michel K, Piyanova A, Oppenheimer H, Dvir-Ginzberg M, Racz I, Ulas T, Imbeault S, et al. A chronic low dose of delta(9)-tetrahydrocannabinol (THC) restores cognitive function in old mice. Nat Med. 2017;23(6):782-7.

71. Sarne Y, Toledano R, Rachmany L, Sasson E, Doron R. Reversal of age-related cognitive impairments in mice by an extremely low dose of tetrahydrocannabinol. Neurobiol Aging. 2018;61:177-86.

72. Brinkmalm G, Sjodin S, Simonsen AH, Hasselbalch SG, Zetterberg H, Brinkmalm A, Blennow K. A parallel reaction monitoring mass spectrometric method for analysis of potential CSF biomarkers for Alzheimer's disease. Proteomics Clin Appl. 2018;12(1). https://doi.org/10.1002/prca.201700131.

73. Duits FH, Brinkmalm G, Teunissen CE, Brinkmalm A, Scheltens P, Van der Flier WM, Zetterberg H, Blennow K. Synaptic proteins in CSF as potential novel biomarkers for prognosis in prodromal Alzheimer's disease. Alzheimers Res Ther. 2018;10(1):5.

74. Sterky FH, Trotter JH, Lee SJ, Recktenwald CV, Du X, Zhou B, Zhou P, Schwenk J, Fakler B, Sudhof TC. Carbonic anhydrase-related protein CA10 is an evolutionarily conserved pan-neurexin ligand. Proc Natl Acad Sci U S A. 2017;114(7):E1253-62.

75. Khalsa DS. Stress, meditation, and Alzheimer's disease prevention: where the evidence stands. J Alzheimers Dis. 2015:48(1):1-12.

\section{Ready to submit your research? Choose BMC and benefit from:}

- fast, convenient online submission

- thorough peer review by experienced researchers in your field

- rapid publication on acceptance

- support for research data, including large and complex data types

- gold Open Access which fosters wider collaboration and increased citations

- maximum visibility for your research: over $100 \mathrm{M}$ website views per year

At BMC, research is always in progress.

Learn more biomedcentral.com/submissions 